\title{
Potential Conflict Among ASEAN Member States in The Implementation of The ASEAN Economic Community
}

\author{
Sugiarto Pramono ${ }^{1}$ \\ Anna Yulia Hartati ${ }^{2}$ \\ Adi Joko Purwanto ${ }^{3}$
}

\begin{abstract}
The findings in this article defy the common assumption that the free market, including the formation of the ASEAN Economic Community (AEC) in Southeast Asia, is correlated with the creation of a spillover and complex interdependency, reducing conflicts between countries in the region. This finding could well contribute as a theory in the academic sphere and as policies in the practical world. The author uses a theoretical framework of structural realism to explain the potential conflict between countries of the Southeast Asian region. There are four potential conflict situations among countries in the implementation of AEC: firstly, the structure of economic disparity. This situation would construct an identity of in-group - out-group or "us" versus "them" in the context of who gains and loses in the AEC. Secondly, similarity of natural resources. This fact led the Southeast Asian countries to compete and create standardization wherein each party is in hostile competition to claim valid findings and arguments associated with efforts to reduce or stop the flow of imports into their respective countries. Thirdly, competition among businesses, in which AEC constructed free market could potentially provoke the emergence of regional trading cartel. Fourthly, the structure of military power. Historical records show that any economic growth occurring in a country will be accompanied by the growth of its military budget.
\end{abstract}

\section{Keywords:}

potential conflict between countries; the ASEAN Economic Community; structural realism.

\begin{abstract}
Abstrak
Temuan dalam artikel ini menentang asumsi umum bahwa pasar bebas, termasuk pembentukan Komunitas Ekonomi ASEAN (AEC) di Asia Tenggara, berkorelasi dengan penciptaan interdependensi yang berlebihan dan kompleks, mengurangi konflik antar negara di kawasan ini. Temuan ini bisa berkontribusi sebagai teori di ranah akademis dan sebagai kebijakan di dunia praktis. Penulis menggunakan kerangka teoritis realisme struktural untuk menjelaskan potensi konflik antar negara di kawasan Asia Tenggara. Ada empat situasi konflik potensial antar negara dalam pelaksanaan AEC: pertama, struktur disparitas ekonomi. Situasi ini akan membangun identitas kelompok dalam kelompok atau "kita" versus "mereka" dalam konteks siapa yang menang dan kalah dalam AEC. Kedua, kesamaan sumber daya alam. Fakta ini membuat negara-

\footnotetext{
${ }^{1}$ Department of International Relations, Faculty of Social and Political Sciences, Wahid Hasyim University, Semarang.

Email: sugiartop@gmail.com

${ }^{2}$ Department of International Relations, Faculty of Social and Political Sciences, Wahid Hasyim University, Semarang.

Email: annayuliahartati@gmail.com

${ }^{3}$ Department of International Relations, Faculty of Social and Political Sciences, Wahid Hasyim University, Semarang.

Email: ajpfisipolhiuwh@gmail.com
} 
negara Asia Tenggara bersaing dan menciptakan standardisasi dimana masing-masing pihak berada dalam persaingan yang tidak bersahabat untuk mengklaim temuan dan argumen yang benar terkait dengan upaya untuk mengurangi atau menghentikan arus impor ke negara masing-masing. Ketiga, persaingan antar bisnis, di mana AEC membangun pasar bebas berpotensi memicu kemunculan kartel perdagangan regional. Keempat, struktur kekuatan militer. Catatan sejarah menunjukkan bahwa setiap pertumbuhan ekonomi yang terjadi di suatu negara akan disertai dengan pertumbuhan anggaran militernya.

\section{Kata Kunci:}

potensi konflik antar negara; komunitas Ekonomi ASEAN; realisme struktural.

\section{Introduction}

The Association of Southeast Asian Nations (ASEAN) is a regional organization in Southeast Asia with 10 member states, namely: Indonesia, Malaysia, Singapore, Thailand, and the Philippines (the 5 founding countries that established ASEAN through the Bangkok Declaration in 1967), while other countries entered in the following years, which are: Brunei (1984), Vietnam (1995), Laos and Myanmar (1997), and Cambodia (1998). The values upheld in the Bangkok Declaration are: to accelerate economic growth, social progress, and cultural development in the Southeast Asian region; to promote regional peace and stability; to promote collaboration and mutual assistance on matters of common interest in the economic, social, cultural, technical, scientific and administrative fields; to maintain close, beneficial cooperation with existing regional and international organizations; and to promote collaboration to enhance education, training and research in the Southeast Asian region.

Nevertheless, in order to achieve these goals ASEAN is committed to uphold the main principles of ASEAN which includes: respect for the independence, sovereignty, equality, territorial integrity, and national identity of all ASEAN member states; respect for the right of every member state to lead its national existence free from external interference, subversion and coercion; non-interference in the internal affairs of ASEAN member states; reliance on peaceful settlement of disputes; renunciation of aggression or use of force; effective collaboration among member states. In its development, economic globalization characterized by liberalization of trade and finance has positioned ASEAN in a global economic competition. A number of ASEAN member states possess proper capacity to keep up with the dynamics of world economy, such as Singapore, Malaysia and Thailand which were able to escape the 1998 financial crisis with relative haste, this unfortunately is not the case with the other ASEAN members.

It is within this context that the ASEAN Economic Community multilateral agreement which was originally planned in the Bali Concord II (1992) and targeted to be realized by 2015 , became a more pressing matter. The integration of ASEAN economy became an alternative option as a strategy in regional development. In more operational terms, liberalization will be undertaken in sectors of goods, services, finance and labor.

However, it seems that the path is not as smooth as imagined, the history of international relations in Southeast Asia provides lessons of conflict and collaboration as well as war and peace in numerous cases of bilateral and multilateral relations among states. Therefore, preparing steps to anticipate and avoid conflict, or even war, as well as establish collaboration and peace is necessary.

One of the earliest step to take is mapping conflict potential. In the context of multilateral collaboration that is exemplified by the AEC, mapping conflict potential among member 
states is conducted by analyzing possibilities where sources of conflict among the countries will most likely emerge. One of the important points that needs serious attention, as the concern of Luhulima (2011: 47), is the existing contradiction between the logic of the AEC, the ASEAN Security Community (ASC), and the ASEAN Socio-Cultural Community (ASCC) which were designed into a package format known as the ASEAN Community. The contradiction is established in that: on the one hand the AEC intends to create a single market and production base for ASEAN, while on the other hand the ASC strives to create "national sovereignty, equality, non-interference, territorial integrity, national identity, shared responsibility, and peaceful cooperation for mutual benefit among nations in Southeast Asia". The issue proposed in this article refers to what will become conflict potential among ASEAN member states in implementing the AEC 2015.

The writers utilized one of the perspectives developed in the study of international relations, that is neo-realism or structural realism, particularly the writings of Kenneth Waltz (1979) in his book the Theory of International Politics. We are of the opinion that there are 2 (two) approaches which can be instrumental in understanding conflict potential in the implementation of the AEC, namely: the concept of conflict potential among states and the theory of structural anarchy.

\section{Conflict Potential Among States}

Conflict of various levels (among individuals, among groups and among countries) has a common principle. Webster (1966) in Pruitt and Rubin $(1966,9)$ defines the term "conflict" as a "fight, battle, or struggle", that is a physical confrontation among several parties. Still according to Webster, the definition of the word subsequently developed into "a sharp disagreement or opposition of interests or ideas". In other words, the definition has begun to touch on the psychological aspects behind physical confrontation. In short, the term conflict has broadened and started to rid its status as a single concept.

Conflict has a positive and negative side. The positive side being: a dialectic in the change process; a facilitator in reconciling various interests; and capacity in strengthening unity. Meanwhile its negative side being: a conflict which is initially light and non-offensive can pave way to offensive actions; problems or issues within the conflict can spread to other issues; focus of conflict can spread from being local to being global; motivation can develop from rational to irrational (Pruitt and Rubin, 1966: 13-17).

We claim that conflict potential among countries is a situation which leads to the rise of interstate conflict. There are two conflict potentials, namely the subjective and objective. The former refers to a psychological situation, while the latter refers to an objective setting external to the agent. There are a number of countries, generally under an authoritarian leadership, that tend to be in conflict with other countries, as exemplified by North Korea under the leadership of Kim Il Jung or Germany under Hitler. This is not the type of conflict potential analyzed in this article, as the writers assume that in the post-cold war era many countries shifted to a democratic system of government and in theory democratic states do not tend to go to war with one another. Hence, there is practically a decrease in conflict potential among countries which originates from internal factors of states (Sorensen, 1993a in Jackson and Sorensen, 1999, 159). The focus of this research is the conflict potential among states that is prevalent at the structural level.

\section{Structural Realism}

The essence in the concept of structural realism is the conviction that the pattern of the international arena is anarchy, wherein it is an arena containing countries with no authority over community members that are in the form 
of states. In other words, international anarchy likens the international system as a primitive society living in the forest with no form of government. The pattern of interpersonal relations among people of primitive society allows conflict to occur among its members. The possibility of emerging conflict is particularly caused by the social structure of primitive society which has neither a superior regulator nor authority consequently leading to an unequal distribution of power.

The structural pattern of anarchy, as illustrated above, is a venue for countries to conduct interactions in the international arena. Although anarchy does not necessarily mean conflict (since anarchy also enables collaboration, as is the argument of neo-liberalists which rivals that of neo-realists, Mansbach, R. W., and K. L. Rafferty (2012, 304-305), the setting of anarchy is a situation of minus authority which implies the absence of regulations thereby opening up possibilities of conflict to occur as a result of clashes in states' interests within an arena absent from said authority.

The researchers inducted a number of conflict potential from structural realism, as follows: structure in the form of economic disparity, structure in the form of natural resource similarity, structure in the form of competition among business actors and structure of military capacity. Four of these international structures present conflict potential in the implementation of AEC.

There are three ideological tracks regarding literature on AEC, namely: liberalism, structuralism, and mercantilism. Firstly, liberalism, writings in this category are characterized by optimism in the future of the AEC. Its main argument is that the AEC correlates with Southeast Asia's prosperity and it serves its part in supporting global multilateralism. It appears that writings with a zeal of liberalism are the most available. This is easily understandable as liberalism is indeed the main paradigm in international trade. A number of notable writers under the umbrella of the liberal ideology among others are: Romprasert (2013); Evienia p., et al (2014); Basudas, et al. (ed.) (2013); Shimizu (2010); Lohani, Bindu N. and Yoshiteru Uramoto (2014).

Included in the liberalism category are writings published by institutions in support of liberalism, such as the following writings under the title: ASEAN 2030: Toward a Borderless Economic Community published by the Asian Development Bank Institute 2014; and a writing titled ASEAN Economic Community 2015: A real opportunity that should not be over-hyped published by Spire Research and Consulting Pte. Ltd. (2013).

Secondly, structuralism, which places the dimension of structure as an independent variable. This ideological track is represented by the writings of Michael G. (2006); Fumitaka et. al. (2012); and Pramono (2010 and 2013). Although not many publications in this second category have enough audacity to oppose the main stream of thought regarding the AEC. Thirdly, mercantilism with the argument that the state becomes a significant actor, albeit not always the only actor. This perspective is written by: Das (2015); and Sahat M. (2014).

As for this article, it can be included in the second category of structuralism, but bearing differences in a number things: firstly, this writing on conflict potential among ASEAN countries in the implementation of the AEC uses a neorealist perspective, which is convinced that the state is a significant actor but sees structure as an independent variable; secondly, writings on conflict potential among states in the implementation of regional economic cooperation such as the AEC are quite rare, this is in part attributable to the perspective of writers who have since the beginning seen collaboration as an effort to reduce conflict, hence conflict potential becomes nearly undetected. This research duly attempts to fill in that gap. 


\section{Methods}

This is a qualitative research which employs in-depth analysis in exploring its subject. In the context of this research: conflict potential among ASEAN states in the implementation of AEC collaboration becomes the target of explorative analysis. Although qualitative research may not be instrumental in creating representative measures, it is highly advantageous to be used for in-depth investigation. This advantage, in our opinion, is especially suitable to the information we intend to excavate in this research.

Regarding the technique for data collection, the researchers have chosen documentation by gathering both official and non-official document data, in the form of scientific books and articles that are relevant to the research topic. The documents were read repeatedly with extreme scrutiny to find themes and categories. The emerging themes and categories were subsequently developed and discussed among the team of researchers.

The technique of data analysis utilized in this research is case study. In order to sharpen the analysis, the case of conflict potential as a result of the implementation of the AEC will be compared to a similar case in Europe. By observing another similar case, the plus-minus of each case is expected to be understood, and thereby allowing to come up with their differences and similarities. This is a significant effort since it will not only enrich the available options in problem solving strategies but it will also open new syntheses as a result of interrelating the cases in the two regions.

The method of summarization chosen by the writers is inductive and deductive. Comparison between the two chosen cases can broaden the scope of summary, allowing the findings of this research to bear proper relevance for policy makers in both ASEAN and European Union.

\section{Discussion}

The free market formed by the AEC is a product of regulations created by the state, hence it is a mistake to assume that free market is a neutral arena void of state interests. This logic brings us to the assumption that in a free market (not withholding the AEC formed free market) conflict among states is present. This argument opposes the conviction of liberalists who assume that (1) spillover (or expansion of collaboration) more easily occurs in free market situation-or the absence of state intervention or using the term stated by Ernst B. Hass (1961: 389) as the meeting of "non-political" aims, while in fact a situation wherein state intervention is not present never really exists, even in a free market, thereby the belief that spillover easily occurs in free market situation needs to be corrected; (2) there is a decrease in the relevance of military instrument in a situation of complex interdependency (Robert O. Keohane and Joseph S. Nye, 1987: 738) because in fact the military budget of Southeast Asian countries are rising in accordance to the wave of liberalization, as will be proven in this chapter's elaboration.

According to the findings of this research, those general convictions were found to be flawed. A vulnerable point in the AEC mechanism is believed to be an entry point for conflict among Southeast Asian countries in the future. It should be reminded early on that conflict or conflict potential among Southeast Asian countries is triggered by a variety of factors (economic, social, political, etc. whether singular or a combination of them) found in various levels of analysis (individual, group of individuals, nation state, group of states within a region, and even the global system [read on the level of analysis in the work of Mas'oed, 1992: 40-42]), nevertheless in this research the topic is limited to: conflict potential (not conflict) among Southeast Asian countries in the implementation of the AEC.

A rough reading on the development of the AEC implementation through mass media 
outlet and official statements of state officials was not able to provide proper assistance in understanding the essence of relational patterns among Southeast Asian countries in terms of multilateral collaboration, therefore a critical reading which attempts to analyze and find the essence of relational patterns among the countries concealed in various piles of formal information is necessary. Based on the conducted analysis, the following 4 (four) situations are found to become conflict potential among countries in the implementation of the AEC, namely: (1) economic disparity; (2) similarity of natural resources; (3) competition of business actors; (4) structure of military power.

\section{Structure of Economic Disparity}

It is difficult to deny the existence of significant economic disparity among ASEAN countries. This is particularly evident in countries which had entered into ASEAN in its later years such as Cambodia, Laos, Myanmar, and Vietnam (or is often called CLMV) that are relatively left behind in comparison to the founding countries (ASEAN 6: Brunei, Indonesia, Malaysia, Philippines, Singapore, and Thailand). This disparity is apparent through what has been mentioned by Darmayadi (2014), that is: in 2010 the richest country in ASEAN was Singapore with an annual income per capita of nearly 45 times greater than the poorest ASEAN country which was Myanmar. In the same year, the proportion of people living below 1 US dollar per day was 33.9 percent in Laos and 28.3 percent in Cambodia, meanwhile in Singapore or Brunei almost no one were living under 1 US dollar per day. The closest implication of that disparity is the capability in utilizing the AEC. The latter mentioned countries are undoubtedly better advantaged with the AEC mechanism while the other countries remaining unstable will find themselves in difficulty if they are reluctant to say that they are being disadvantaged by the AEC mechanism.
In the context of the AEC, the setting of economic disparity essentially becomes a precondition which could easily trigger interstate conflict. The logic of national interest will guide foreign politics to be directed at maximizing profit and minimizing loss so it is extremely easy to incite suspicions from those who have yet acquired advantages (if reluctant to say: disadvantaged) from the AEC mechanism. Therefore, it is no surprise that ASEAN countries prefer (at least up to the writing of this research) to engage in economic relations with countries outside the region instead of with its neighboring countries within the region. Myanmar is more intimate with India, while Cambodia and Laos gets closer to China, and Singapore to Europe and America. Hard evidence regarding the matter is in the high rate of extra regional trade which reached 1.9 trillion US dollars, in comparison, the intra regional trade only amounted 609 billion US dollars. This fact is also an indicator which demonstrates how ASEAN cohesiveness remains to be far from expected. This can be compared to EU's much smaller extra regional trade, which was 1.7 trillion US dollars in comparison to its intra regional trade which reached 2.8 trillion US dollars (Bone, Domic, 2016). These figures show the actual strength of EU integration.

Table 1.

Comparison of Intra and Extra Regional Trade in EU and ASEAN

\begin{tabular}{llcl}
\hline & \multicolumn{1}{c}{ EU } & ASEAN & PERCENTAGE \\
\hline INTRA & \$ 2.8 Trillion & \$ 609 Billion & $62 \%$ \\
EXTRA & \$ 1.717 Trillion & \$ 1.9 Trillion & $24 \%$ \\
\hline
\end{tabular}

Source: Bone, Domic (2016)

This situation will trigger a polarization in the attitudes of Southeast Asian countries towards the AEC. For Singapore, Malaysia, Indonesia, Philippines, and Thailand, the AEC is considered significant as it is in line with their national interest (market expansion 
throughout the Southeast Asian region), while for Cambodia, Laos, Myanmar, and even Vietnam it can be observed that their support towards the AEC is not as aggressive as the countries advantaged by the AEC mechanism. This situation will construct an in-group/ out-group or "us" versus "them" identity in the context of who is advantaged and disadvantaged in the AEC. Even though it does not automatically create conflict, the situation becomes an established precondition for conflict among countries in Southeast Asia.

\section{Similarity of Natural Resources}

There are five complete natural resources in the Southeast Asian region (strategic location, forest, sea, land, and mine) - Southeast Asia has an abundance of natural resources in the form of: (1) Strategic location. It is considered strategic as the territory is located in between two oceans namely the Indian and Pacific Ocean. This leads shipping routes to and fro these two oceans having to run through the Malacca Strait, the Sunda Strait, the Bali Strait, and the Lombok Strait. Southeast Asia becomes a connecting region between countries of East Asia (japan, North Korea, South Korea, China, Taiwan) and countries of West Asia and South Asia. Additionally, Southeast Asia also connects the mainland regions of Asia to Australia and New Zealand. (2) Forests. It is one of the natural resources bearing a role of utmost importance as it maintains wealth in the form of flora and fauna that is of immensely high value. Its extent covers almost the whole region of Southeast Asia, except for Singapore. In addition to having high economic value, forests also function as a stabilizer of global temperature and a reservoir of ground water storage. (3) Seas. The marine area of Southeast Asia covers the Arafura Sea, the Java Sea, the South China Sea, the Sulawesi Sea, the Malacca Strait, the Makassar Strait, the Karimata Strait, the Bali Strait, and the Lombok Strait. The seas also function as: a source of water vapor resulting in rain, a source for mining of natural oil and gas, a source of income in the tourism sector, a source of income in the fishery sector, and a relatively affordable means of transportation. (4) Land. Most land in Southeast Asia are highly fertile volcanic land. This is due to the fact that two volcanic belts, namely the circumPacific and the Mediterranean, run through the Southeast Asian region. The land's fertile condition leads to Southeast Asia becoming the largest paddy producing region in the world. Vietnam, Thailand, Indonesia, and Myanmar are Southeast Asia's granaries. (5) Mining products. Countries in Southeast Asia are also immensely huge and influential producers of mining commodities on a global scale. Malaysia is a producer of bauxite, Brunei is a producer of natural oil and gas, and Indonesia is a producer of natural oil, natural gas, coal, and copper.

The similarity of natural resources in ASEAN instigates competition of a product with the advent of product standardization. One of the supporting elements of the AEC is the single market and mutual basis of production which brings about a consequence of eliminating trade barriers which were previously fragmented in the 10 national markets. The operational elimination of these trade barriers can be observed through the reduction of tariffs to a tolerance of $0-5 \%$. Meanwhile, from a structural realism perspective, as elaborated in the previous passages, an international system with a pattern of anarchy (Waltz, Kenneth. 1979), which is a situation wherein no authority is present above the states. Although conflict is always found in anarchy, conflict does not necessarily appear in the form of physical conflict such as war or aggression.

Still according to structural realism, states behavior is guided by the anarchic nature of the international system hence leading their behavior to be characterized as self-help, egoistical, oriented towards national interests, and indifferent to the interests of neighboring countries. Bearing such characteristics, it is 
difficult to imagine that states will remain silent (do not engage in market intervention) when seeing that their national interests are under the interference of the AEC constructed market mechanism.

The AEC along with its various supporting elements (single market and production base; highly competitive economic region; equitable economic development region; and a region fully integrated into the global economy) is constructing Southeast Asia into a free market, which is a situation wherein state intervention is minimized to its lowest point, if not eliminated all together. On the other hand, sovereignty is a given absolute for a state, including economic sovereignty. The surge of import caused by the design of the AEC regulation has the potential to leave various local products in the periphery if they are incapable of innovating. The essence of economic sovereignty is under threat. One of the steps which can be taken to protect economic sovereignty is by protecting certain local products using means that are considered not in violation of the AEC regulation, for instance by resorting to tactics of product standardization, so that various imported goods must conform to national standards in order to compete in the country.

Product standardization tactics can be employed by implementing an obligation that every imported product/goods be supplied with a manual book written in the local national language, halal label from a national institution, or implementation of special requirements for fruit products such as imported bananas with a minimum length of $14 \mathrm{~cm}$ and width of $2.7 \mathrm{~cm}$, the fruit should not be spoiled and ripe and so forth (the last requirement is implemented in the European Union). Product standardization tactics employed by the importing country has the potential to be understood both positively and negatively by other countries. A positive understanding of product standardization, as an example, can be the exporting country interpreting it as a warning to increase their product quality and efficiency so that it becomes more competitive and acceptable by consumers in other countries. While a negative outlook of product standardization is that it is considered as an effort in obstructing the entry of various product so that it will be responded with a counter attack by obstructing the entry of other product. This is undoubtedly conducted with a variety of well designed strategies making it able to pass undetected through the AEC regulation. This situation has the potential to happen in all ASEAN member states. Even more so with the similarity in natural resources. It is plain to see that the varieties of crops, fruits and livestock in the ASEAN countries are relatively similar. Paddy, palm, rubber, numerous fruits and livestock are found throughout Thailand, Indonesia, Cambodia, Laos, Myanmar, and Vietnam. In short, it is extremely difficult to differentiate whether product standardization is an effort to increase product quality or a country strategy employed to lessen its import. It is this kind of situation that will easily trigger interstate conflict.

An interesting illustration is the case of genetically modified (GM) crops as explained by Mansbach, R. W., and K. L. Rafferty (2012: 636-637). In 1998, the EU implemented a moratorium on GM food crops from the United States. Based on the concern regarding the impact of GM product upon human health, such as the possibility of GM food crops in causing new allergies, or increasing the species of current flora and fauna which would reduce biodiversity and amplify the possibility of disaster if a disease struck the existing species. GM plants and animals are common to the US. In fact, most string beans, cotton and corn in the US are planted from genetically modified seeds. The people of the US consider GM food crops bear a lot of benefit, such as: GM crop is a means for efficiency and for increasing the quality and quantity of food, and for enhancing resilience against pests, additionally, GM animals are healthier and more productive, 
even the environment gains benefit from the reduction in the use of pesticide and herbicide from the conservation of water and land. Farmers and producers of GM seeds in the US, such as Monsanto, had undertaken arduous lobbying in the effort of opening the European market by reasoning that labeling is costly and it unequally implies that the product is unsafe in some respect. Hence in 2006, a WTO panel stated that the EU had illegally restricted a number of GM product.

Similar conflict also has the potential to occur in Southeast Asia, wherein the member states compete to create standardization and each party mutually struggle to claim validity for various findings and argumentations regarding the effort in reducing or stopping the surge of import into their countries respectively. This situation subsequently creates tension in the relationship among Southeast Asian countries.

\section{Competition of Business Actors}

Cartel is a prohibited collaboration in a free market. Law No. 5 year 1999 on the Prohibition of Monopolistic Practices and Unfair Business Competition included cartel into the category of prohibited agreement (Chapter III, Section V). Cartel can simply be understood as a collaboration among big business actors in one type of product with significant power to monopolize the market and fix the prices in order to divide the market so it sees no other competition and it shuts the door for new competitors. The AEC enables a highly intensive interaction among business actors in Southeast Asia. In a pre-AEC situation in which there is market fragmentation along with its various inherent trade barriers, it would be very difficult for regional cartel to emerge, however, the absence of those trade barriers will serve as a fertile ground for the growth of business cartels in Southeast Asia, particularly in the palm oil and rice sector.

Take Indonesian Palm Oil Pledge (IPOP) for instance, it is a palm oil cartel signed by six companies, namely: Wilmar International Ltd, Cargill Inc, Musim Mas, Astra Agro Lestari, Asian Agri dan Golden Agri-Resources. In addition, five member states (Thailand, Vietnam, Cambodia, Myanmar, and Laos) have blatantly planned to discuss the establishment of a rice producer cartel. Although its normative reasoning is to create price stability, it is difficult to deny that the behavior of the five states (in which four of them are the CLMV countries) is an effort to increase their bargaining position in facing the ASEAN 6. This assumption becomes more convincing with the Philippines' concern over the matter as a rice importer (voaindonesia.com: 5 Negara Asia Bahas Pembentukan Kartel Beras - 5 Asian Countries Discuss Formation of Rice Cartel).

A AEC constructed free market has the potential in instigating the rise of regional trade cartel. This is similar to the Organization of the Petroleum Exporting Countries (OPEC) in the Middle East. They collaborate to establish pricing and allocate markets, so there is no competition. Trade cartel also has the potential to hamper the rise of new competitors. With immense economic power the rice cartel could monopolize the rice market in Southeast Asia. The emergence of international trade cartel following the AEC is also a point of concern for the Commission for the Supervision of Business Competition (KPPU). ${ }^{4}$

If a rice cartel were to emerge in Southeast Asia, there will be tension in the relationship between rice producing countries (Indonesia, Malaysia, Thailand, Cambodia, Laos, Myanmar, Vietnam) and rice importing countries (Singapore, Philippines, Brunei). If no political intervention and coordination are employed, the strain in the relationship will have the potential to influence trade relations of other various product. Firstly, rice is a staple food in Southeast Asia, those controlling the distribution of rice will control Southeast Asia; secondly, Singapore is a channel which connects the value chain of various product

\footnotetext{
${ }^{4}$ http://www.kppu.go.id/id/splash/
} 
between Southeast Asian countries and extra regional countries. It is hard to deny the fact that business and political relations in Southeast Asia go together like a horse and carriage. Strong relations among policy makers at the national level with various business cartels will weaken the building of free market which is currently being strengthened by the AEC. This situation will consequently cause further tension in inter-state relations.

\section{Structure of Military Power}

History records show that every economic growth a country experiences will be matched with growth in its military expenditure. The relation between the two variables ("economic growth" and "increase in security budget") is very easy to understand. The greater the economic expansion a country undertakes, the greater its need to secure market access, this condition encourages countries experiencing economic progress to also focus on strengthening military development, hence economic growth also has the potential to create a security dilemma.

To put simply, a security dilemma is understood as such: if a country, say country $x$, in order to secure its economic growth raises its security budget, then this will often be interpreted as a threat by other countries, say country $z$, which will subsequently trigger a response from country $z$ to increase its arsenal as well. When country $z$ has increased its security budget, this will be interpreted similarly by country $\mathrm{x}$, so country $\mathrm{x}$ will eventually raise their security budget again, so on and so forth. This is what is known as security dilemma.

Security dilemma in Southeast Asia is very likely to occur. Particularly for ASEAN member states, the AEC will create new markets for the expansion of their various product, leading to the inevitable economic growth. When progress of economic growth begins to drastically climb, it is foreseeable that they will attempt to maintain the security of their respective economic growth. It is this setting that has the potential to construct security dilemma. Do keep in mind the Second World War which originated in Europe and was initiated with an arms race among the countries of that continent. The growth in military spending of Southeast Asian countries can be illustrated as follows: in 2012, Singapore and Indonesia collectively reached almost $57 \%$ of the total security budget of ASEAN countries. The security budget of the five big ASEAN countries (Singapore, Indonesia, Thailand, Malaysia, Philippines) is estimated to have reached $\$ 61.6$ billion US dollars by the year 2020 from a total of $\$ 29.3$ billion US dollars in 2012, or a CAGR of $9.8 \%$ during the projection period. Most of the expenditure is assumed to be driven by the rise in Indonesia's spending which increased by $17 \%$ CAGR in that period. In 2020, it is predicted that Indonesia will contribute up to almost $40 \%$ or approximately $\$ 24.6$ billion US dollars from the ASEAN security budget which is followed by Singapore with 23\% (\$14 billion US dollars) and Thailand with $17 \%$ (\$10 billion US dollars. ${ }^{5}$

\section{Conclusion}

This article provides opposing evidences to the commonly believed perspective that supports the AEC policy. Supporters of the AEC are convinced that the free market developed in Southeast Asia correlates to the reduction of interstate conflict based on the complex interdependency and spillover effect it incites, yet this article shows that the AEC paves the way for conflict potential among Southeast Asian countries. There are four conflict potential that needs to be anticipated regarding the implementation of the AEC, namely: Firstly, structure of economic disparity. The group of ASEAN latecomers, that is the CLMV countries, undeniably have a relatively lower economic

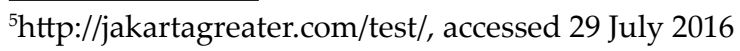


standing compared to the ASEAN 6. This disparity bears implication on the beneficial value acquired through the implementation of the AEC. The ASEAN 6 countries clearly benefit from the market expansion to new frontiers that were previously restricted territory, while the CLMV countries are yet to see the benefit they acquire, if not saying that they are actually being disadvantaged. The foreseeable consequence is the emergence of in group - out group identity based on the beneficial value obtained from the AEC. This setting positions them (CLMV and ASEAN 6) in direct confrontation.

Regarding this structural conflict potential, an effort to deconstruct the existing structure should be made so there is no longer any potential for conflict. It can be done through various ways, one that we are offering is through cross subsidy in which countries with certain economic standing provide grant assistance to those with certain poverty level. This cross subsidy scheme will establish a stronger and more amicable identity as well as deconstruct international anarchy in Southeast Asia.

Secondly, similarity of natural resources. This similarity instigates competition. The source of the competition is a contest in product standardization. This effort is considered as appropriate and rational, however, its potential in creating interstate conflict should be anticipated. Trade wars will occur among Southeast Asian countries. For if one country could not retaliate in the same sector, it will attempt to do so in a different one. One of the ways to be employed in order to minimize interstate conflict is by creating product standards.

Thirdly, competition of business actors. With the implementation of the AEC, trade cartels have the potential to emerge at the regional level. Business giants in production of rice and palm oil have the potential to establish cartels at the regional level which will consequently trigger interstate conflict. Rice producing countries such as CLMV plus Indonesia and Malaysia will confront rice importing countries such as Philippines and Singapore. Regarding the issue of cartel, a strategy can be employed by completing AEC regulation with various stipulations that greatly narrows the possibility for cartels to grow.

Fourthly, structure of military power. Interstate security dilemma in Southeast Asia. The AEC opens up new frontiers for market expansion, wherein economically well established countries will become more aggressive in seeking market expansion thus generating economic growth. As the economic growth of a country is considered to be of vital importance, there is no other way but to secure it. The frequently utilized means of protection is by raising the budget for military spending. When a country's budget for military expenditure increases, it will instigate a security dilemma which will turn into a conflict potential.

A solution to minimize conflict potential is by prioritizing the goal of becoming a real community. This needs to be reviewed so that ASEAN does not merely become a vessel, as it should be a vessel bearing contents that are beneficial to its entire community. As an example is geographical spill-over occurring in integrated areas that are capable of alleviating state boundary issues which are particularly problematic in the Southeast Asian region. In conclusion, it is important for ASEAN to implant and embed core values of the ASEAN community throughout all its societal elements which will subsequently urge ASEAN to become a real community for an integrated Southeast Asia towards creating regional peace.

\section{References}

Arifin, S., Winantyo, R., Djaafara, R. A., Budiman, A. S. (2008). Masyarakat Ekonomi ASEAN 2015: Memperkuat Sinergi ASEAN di Tengah Kompetisi Global. Jakarta: Elex Media Komputindo dan Bank Indonesia.

Badan Standardisasi Nasional. (n.d). Hadapi ASEAN Economic Community 2015, 
Kedeputian IPS BSN Bahas Strategi Promosi Standardisasi. Retrieved July 29, 2016, from http://bsn.go.id/main/berita/berita_ $\operatorname{det} / 4492 \#$.V5qrvk9OPMx.

Baristakata.com. (2006). Mengenal Masyarakat Ekonomi ASEAN. Retrieved June 25, 2016, from https://baristakata.com/2016/01/05/ mengenal-masyarakat-ekonomi-asean/,

Basudas, Sanchita. (et.al, 2013). The Asean Economic Community: A work in progress. Singapore: ADB dan ISEAS Publishing.

Benedicta Evienia p., (et.al, 2014). Pandangan Pelaku Pendidikan di Universitas terhadap Pemberlakuan Masyarakat Ekonomi ASEAN 2015. Bina Ekonomi Majalah Ilmiah Fakultas Ekonomi Unpar, 18(2).

Bone, Domic. (2016). Intra-Asean Trade: Are you building your ASEAN dream by taking advantage of intra-regional trading opportunities?. Retrieved from https://www. linkedin.com/pulse/intra-asean-tradeyou-building-your-asean-dream-takingdominic-bone

Bremmer, Ian. (2009). State Capitalism Comes of Age: The End of the Free Market?. Retrieved July 19, 2016, from https://www.foreignaffairs. com/articles/united-states/2009-05-01/statecapitalism-comes-age . (2010). Akhir Pasar Bebas, The End of the Free Market: Siapa Pemenang dalam Perang antara Negara dan Swasta?. (Alex Tri Kantjono Widodo, Trans). Jakarta: PT Gramedia Pustaka Utama.

Burmansyah, Edy. (2014). Rezim Baru ASEAN: Memahami Rantai Pasokan dan MEA. Jakarta: Pustaka Sempu.

Cipto, Bambang. (2007). Hubungan Internasional di Asia Tenggara: Teropong terhadap Dinamika Realitas dan Masa Depan. Yogyakarta: Pustaka Pelajar.

Darmayadi, Andrias. (2015). Kesenjangan Pertumbuhan Ekonomi di Negara CLMV dan Pengaruhnya terhadap Asean Economic Community (AEC) 2015. Jurnal Ilmu Politik dan Komunikasi Unikom, 4(1). Retrieved
July 27, 2016, from http://jipsi.fisip.unikom. ac.id/_s/data/jurnal/volume-04-no-1/ kesenjangan-pertumbuhan-ekonomi-dinegara-clmv-andrias-darmayadi.pdf/pdf/ kesenjangan-pertumbuhan-ekonomi-dinegara-clmv-andrias-darmayadi.pdf

Das, Sanchita Basu. (2015). The ASEAN Economic Community: An Economic and Strategic Project. Singapore: ISEAS Perspectives.

Direktorat Perundingan Perdagangan Jasa. (2015). Kesiapan Sektor Jasa Konstruksi Nasional Menghadapi Masyarakat Ekonomi Asean (MEA) 2015. Retrieved July 29, 2016, from http:// aeccenter.kemendag.go.id/media/177237/ buku-konstruksi-oktober-2015.pdf

D'Laiqa, Rika. (2013). Status Paspor (Biasa) Indonesia di Negara-Negara ASEAN. Retrieved July 30, 2016, from http://www. dlaiqa.com/2013/11/status-paspor-biasaindonesia-di-negara.html

Furuoka, Fumitaka, (et.al, 2012). Making of the Asean Community: Economic integration and its Impact on workers in Southeast Asia. Journal of Arts, Science \& Commerce. III, 2(1), April.

Gilpin, Robert. (2001). Global Political Economy: Understanding The International Ecocomic Order. New Jersey: Princeton University Press.

\& Gilpin, Jean Millis. (2002). Tantangan Kapitalisme Global: Ekonomi Dunia Abad ke 21. Diterjemahkan oleh: Haris Munandar. Jakarta: Raja Grafindo.

Hadiwinata, Bob Sugeng. (2002). Politik Bisnis Internasional. Yogyakarta: Penerbit Kanisius.

Hass, Ernst. (1961). International Organization: The European and Universal Process. International Organization, 15(3), 66-392. Retrieved July 19, 2016, from http://www.lsu. edu/faculty/lray2/teaching/7971_1s2009/ haas1961.pdf

Jackson, R., dan Georg Sorensen. (1999). Pengantar Studi Hubungan Internasional. Yogyakarta: Pustaka Pelajar. 
Jakarta Greater. (2014). Merebut (Kembali) Hegemony Militer Dari Singapura. Retrieved July 29, 2016, from http://jakartagreater. com/test/

Kementerian Perdagangan. (2011). Informasi Umum Mengenal Masyarakat Ekonomi ASEAN: ASEAN Community in a Global Community of Nations. Jakarta: Direktorat Jenderal Kerja Sama Perdagangan Internasional.

Keohane, R. O. \& Joseph S. Nye. (1987). Power and Interdependence Revisited Power and Interdependence. International Organization, 41(4), 725-753. Retrieved from http://www. ri.ie.ufrj.br/intranet/arquivos/power_and_ interdependece.pdf

Luhulima, C. P. F. (2011). Dinamika Asia Tenggara Menuju 2015. Jakarta: Pustaka Pelajar dan P2P-LIPI.

Mansbach, R. W., dan K. L. Rafferty. (2012). Pengantar Politik Global. (A. Asnawi, Trans). Bandung: Nusamedia.

Mas'oed, Mochtar. (1990). Ilmu Hubungan Internasional: Disiplin dan Metodologi. Yogyakarta: LP3ES.

. (1989). Studi Hubungan Internasional: Tingkat Analisa dan Teorisasi. Yogyakarta: PAU Studi Sosial UGM.

Pasaribu, Sahat M. (2014). Kajian Kesiapan Sektor Pertanian Menghadapi Pasar Tunggal ASEAN 2015 (Research proposal guidance 2014). Jakarta: Pusat Sosial Ekonomi dan Kebijakan Sosial; dan Badan Penelitian dan Pengembangan Pertanian.

Plumer, Michael G. (2006). East ASEAN Economic Integrations and Europe: Can ASEAN Learn from The EU?. Emerging Development in East Asia FTA/ EPAs. Core University Programe Conference October 27-28, October 2006.

Pramono, S. (2010). Meneropong Masa Depan Komunitas ASEAN 2015. Spektrum, 7(1), January.

(2013). Kesenjangan Kawasan dan Strategi Pembagunan Lokal menghadapi
ASEAN Economy Community 2015. Spektrum, 14(2).

Pruitt dan Rubin. (2004). Teori Konflik Sosial. (Helly P. Soetjipto, Trans). Yogyakarta: Pustaka Pelajar.

Rais, Amien. (2008). Agenda Mendesak Bagsa, Selamatkan Indonesia. Yogyakarta: PPSK Press.

Romprasert, Suppanunta. (2013). Asian Economic Community with Selected Macroeconomic Variables for Exports Sustainability. International Journal of Economics and Financial Issues, 3(3), 602605.

Shimizu, Kazushi. (2010). ASEAN Economic Integration in the World Economy: Toward the the ASEAN Economic Community (AEC). Econ. J. of Hokkaido Univ. 39, 77-88. Retrieved from http://eprints.lib.hokudai. ac.jp/dspace/bitstream/2115/44174/1/ EJHU_39_77.pdf

VOA Indonesia. (2016). KPPU Akan Selidiki Praktik Kartel Perusahaan Minyak Kelapa Sawit. Retrieved July 28, 2016, from http:// www.voaindonesia.com/a/kppu-akanselidiki-praktik-kartel-perusahaan-minyakkelapa-sawit/3285244.html

Waltz, Kenneth. (1979). Theory of International Politics. USA: McGraw-Hill, Inc.

Winarno, Budi. (2010). Melawan Gurita Neoliberalisme. Jakarta: Penerbit Erlangga. . (2009). Pertarungan Negara versus Pasar. Yogyakarta: Media Pressindo.

Yufani, Elsa dan Syafri Harto. (n.d). Implikasi ASEAN Economic Community Blueprint terhadap Perkembangan Perdagangan Indonesia ke Singapura. Retrieved July 27, 2016, from http://download.portalgaruda.org/article. php? article $=185832 \&$ val $=6444 \&$ title $=$ IMP LIKASI\%20ASEAN\%20ECONOMIC\%20 COMMUNITY\%20BLUEPRINT\% 20 TERHADAP\%20PERKEMBANGAN\%20 PERDAGANGAN\%20INDONESIA $\% 20$ KE\%20SINGAPURA 